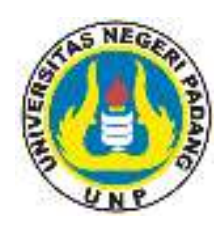

\title{
PENGARUH MEDIA GAMBAR TERHADAPKEMAMPUAN DOKKAI SISWA KELAS X SMA NEGERI 6 PADANG TAHUN 2018-2019
}

\section{Salman Dinilhaq ${ }^{1}$, Hendri Zalman ${ }^{2}$}

${ }^{1}$ (Mahasiswa Pendidikan Bahasa Jepang, Bahasa dan Sastra Inggris, Fakultas Bahasa dan Seni, Universitas Negeri Padang)

${ }^{2}$ (Dosen Pendidikan Bahasa Jepang, Bahasa dan Sastra Inggris, Fakultas Bahasa dan Seni, Universitas Negeri Padang)

Email Penulis : salmanputra35@gmail.com

\begin{tabular}{l} 
Sejarah Artikel \\
\hline Submit $: 2020-02-12$ \\
Diterima $:$ \\
Diterbitkan : $2020-07-20$
\end{tabular}

Kata Kunci:

Reading. Media, Picture

Abstrak
Four aspects, namely: listening skills, speaking
skills, writing skills, and reading skills. Reading skills
take an important role in learning Japanese at the
high school level. In reading lessons in Japanese,
students are required to also be able to read to
understand what they are reading. Based on what the
researchers observed when implementing
educational practices (PLK) at SMAN 6 Padang
showed the lack of interest and ability to read
Japanese students. So that the achievement of
learning goals is not optimal. Therefore, certain
media are neededto make it easier to attract students
to improve reading skills. The use of image media can
overcome the above problems. The purpose of this
study was to find out how the influence of the picture
media on the reading ability of class X students of
SMAN 6 Padang. This study uses quasi-experimental
research, with posttest tonly control group design.
While the sampling technique uses purposive
sampling technique. The sample in this study were
students of class X MIPA 1 andX MIPA 5 with a total
of 69 people. The results of data analysis, obtained
tcount with a significance level of 0.05\% is 2.00 with
degrees of freedom dk = n1 + n2-2.This means that
tcount > table (2.50> 2.00). Then the hypothesis is
accepted,because tount table.

\section{PENDAHULUAN}

Bahasa merupakan alat komunikasi yang digunakan untuk menyampaikan ide, pikiran, hasrat dan keinginan kepada orang lain. Oleh karena itu, dalam berbahasa diperlukan keterampilan dan pemahaman antar dua belah pihak untuk menghindari miskomunikasi. Dalam kajian ilmu bahasa, keterampilan berbahasa terdiri atas empat aspek, yaitu: keterampilan mendengar, keterampilan berbicara, keterampilan menulis, dan keterampilan membaca.

Menurut Sutedi (2004:2), saat kita berkomunikasi dengan orang lain baik secara lisan ataupun tulisan, orang tersebut bisa mengerti apa yag kita maksud 
karena memahami makna yang terdapat pada bahasa yang kita gunakan. Jadi, bahasa adalah media untuk menyampaikan suatu makna kepada orang baik secara lisan ataupun tulisan.Oleh karena itu, pembelajaran membaca menjadi sangat penting.

Keterampilan membaca mengambil peran penting dalam pembelajaran Bahasa Jepang tingkat SMA. Pada pelajaran membaca dalam mata pelajaran Bahasa Jepang siswa dituntut untuk juga bisa membaca memahamiapa yang mereka baca.

Kemampuan membaca berdasarkan cara membaca dibagi menjadi membaca bersuara atau membaca nyaring dan membaca pemahaman. Menurut Tarigan (1979: 23) membaca nyaring adalah kegiatan yang merupakan alat bagi guru, murid, ataupun pembaca bersama-sama dengan orang lain atau pendengar untuk menangkap serta memahami informasi, pikiran dan perasaan seorang pengarang.

Sementara kemampuan pemahaman adalah membaca yang bertujuan untuk memahami standar-standar kesusastraan, resensi kritis, drama tulis dan polapolafiksi. Dalam pembelajaran Bahasa Jepang, kemampuan membaca tingkat SMAlebih ditekankan kepada membaca pemahaman.

Berikut adalah nilai rata-rata Ujian MID Semester genap masing-masing kelas X IPA tahun pelajaran 2018/2019:

Tabel 1: Nilai rata-rata ujian MID Semester Genap kelas X IPA 2018/2019

\begin{tabular}{ccc}
\hline NO & Kelas & Nilai \\
\hline 1 & X IPA 1 & 78 \\
\hline 2 & X IPA 2 & 82 \\
\hline 3 & X IPA 3 & 70 \\
\hline 4 & X IPA 4 & 82 \\
\hline 5 & X IPA 5 & 81 \\
\hline
\end{tabular}

Berdasarkan data diatas diketahui bahwa nilai mata pelajaran Bahasa Jepang masih tergolong rendah. Berdasarkan hasil observasi peneliti selama menjalani mata kuliah PLK di SMAN 6 Padang. Hal ini disebabkan karena siswa kesusahan mengingat kosa kata, kalimat, dan memahami isi bacaan.

Berdasarkan hasil wawancara peneliti dengan guru mata pelajaran Bahasa Jepang SMA N 6 Padang, peneliti berasumsi bahwa diperlukannya media pembelajaran yang dapat membantu siswa khususkan pada kemampuan membaca.

Media pembelajaran yang diduga efektif adalah media visual, menurut Sudjanto (2010:87 ) yang termasuk media visual sederhana adalah, benda sebenarnya dan benda tiruan, foto dan gambar, biagram dan diagram, dan papan tulis. 
Yusnani (2012) juga menyimpulkan dalam penelitiannya, agar pembelajaran bahasa menjadi menyenangkan dan sederhana, maka salah satu media yang bisa digunakan adalah Comic Strip.Sejalan dengan itu, Menurut Fajar(2013) dalam penelitiannya yang berjudul "Penggunaan Media Manga (komik jepang) dalam Pembelajaran Menulis Karangan Narasi (Penelitian Eksperimen Semu pada SiswaKelas XI SMK N 11 Bandung Tahun Ajaran 2012/2013). Penggunaan media manga dalam pembelajaran menulis narasi terbukti efektif.

Hal itu dibuktikan dengan peningkatan nilai rata-rata kemampuan menulis pada sampel penelitian. Nilai rata-rata pretest siswa sebesar 53,27 dan posttest sebesar 63,27 Selanjutnya dilakukan uji hipotesis dapat diketahui bahwa thitung sebesar 6,67 dan ttabel dengan taraf signifikan 5\% atau tingkat kepercayaan 95\% sebesar 1,76. Hal tersebut berarti bahwa $(6,67>1,76)$ atau thitung $>$ ttabel, dengan begitu perbedaan antara nilai pretest dan posttest terbukti signifikan.

Berdasarkan penjelasan diatas dapat diasumsikan bahwa media visual yang didesain menyesuaikan kebutuhan materi pelajaran akan berpengaruh kepada kemampuan membaca siswa dalam pelajaran Bahasa Jepang.Untuk membuktikan asumsi tersebut perlu diadakan penelitian dengan judul, "Pengaruh Media gambar Terhadap Kemampuan Membaca Bahasa Jepang Siswa Kelas X SMA Negeri 6 Padang tahun 2018-2019”.

\footnotetext{
${ }^{1}$ Mahasiswa Prodi Pendidikan Bahasa Jepang FBS UNP lulus pada Maret 2020

2 Dosen Prodi Pendidikan Bahasa Jepang FBS UNP
}

\section{METODE PENELITIAN}

Metode yang digunakan dalam penelitian ini adalah metode eksperimen yang bertujuan untuk menguji pengaruh media gambar terhadap kemampuan membacasiswa kelas XSMA N 6 Padang. Sebagaimana diungkapkan oleh Arikunto (2000 : 12)“Penelitian eksperimen merupakan penelitian yang dimaksudkan untuk mengetahui ada tidaknya akibat dari "sesuatu" yang dikarenakan pada subjek selidik. Dengan kata lain penelitian eksperimen mencobameneliti ada tidaknya hubungan sebab akibat. Caranya adalah dengan cara membandingkan satu atau lebih kelompok eksperimen yang diberi perlakuan dengan satu atau lebih kelompok eksperimen yang di beri perlakuan dengan satu atau lebih kelompok pembanding yang tidak di beri perlakuan".

Jenis penelitian ini adalah penelitian kuantitatif. Penelitian pada dasarnya adalah suatu kegiatan atau proses sistematis untuk memecahkan masalah yang dilakukan dengan menggunakan metode ilmiah. Oleh karena itu, penelitian ini dikatakan penelitian kuantitatif karena data yang diolah berupa angka-angka, yaitudalam bentuk skor hasil belajar siswa sebelum dan sesudah menggunkan media gambar.Arikunto (2010:12) mengatakan bahwa "penelitian kuantitatif adalah penelitian yang menggunakan angka, dimulai dari mengumpulkan data, kemudian penafsiran dan terakhir ditampilkan hasilnya". Populasi menurut Arikunto (2006:130) "Populasi adalah keseluruhan objek penelitian". Populasi dalam penelitan ini adalah seluruh siswa kelas XSMA N 6 Padang jurusan IPA dari lima kelas yang berjumlah 177 orang siswa. Berdasarkan data tersebut, populasi dalam penelitian ini adalah seluruh siswa kelas XSMA N 6 Padang dari 
kelas X IPA 1 sampai kelas X IPA5 berjumlah 177 siswa.

Sampel menurut Arikutno (2010:174) adalah "Sebagian atau wakil dari populasi yang diteliti". Penarikan sampel dalam penelitian ini akan dilakukan dengan purposive sampling. Menurut Sutedi (2009:181), teknik purposive sampling adalah pengambilan sampel yang didasarkan atas pertimbangan peneliti itu sendiri, dengan maksud atau tujuan tertentu yang bisa dipertanggungjawabkan secara ilmiah. Dari lima kelas X MIPA yang belajar bahasa Jepang pada tahun ajaran 2018-2019 di SMAN 6 Padang, sampel dalam penelitian ini diambil sebanyak dua kelas, yaitu kelas X MIPA 5 sebagai kelas eksperimen dan kelas X MIPA 1 sebagai kelas kontrol. Hal ini didasari dengan alasan, (1) karena kedua kelas diajar oleh guru yang sama, (2) jumlah siswa antar kelas sama, (3) nilai kedua kelas tidak terlalu jauh berbeda, (4) direkomendasikan oleh guru mata pelajaran sebagai kelas untuk peneliti meneliti.

Tahapan yang dilakukan dalam penelitian ini yaitu, pertama dengan memberikan treatment kepada sampel. Kedua, memberikan post-test kepada sampel. Ketiga, melakukan uji hipotesis dengan membadingkan $t_{\text {hitung }}$ dan $\mathrm{t}_{\text {tabel. }}$.

\section{HASIL DAN PEMBAHASAN}

Data dalam penelitian ini adalah hasil yang diperoleh dari teskemampuan membaca berupa tes tulis dari kelas sampel. Soal tes berupa objektif pilihan ganda sebanyak 30 butir. Setelah dilaksanakan tes diperoleh data dari kelas eksperimen dan kelas kontrol. Tes kemampuanmembaca diikutioleh 33 siswa kelas eksperimen dan 32 siswa kelas control. Tes pada kedua kelas sampel ini setelah dilakukan penyekoran, penilaian, selanjutnya dilakukan perhitungan rata-rata, dan simpangan baku masing-masing.

Berdasarkan hasil penelitian, untuk indikator Indikator 1 diperoleh rata-rata hitung kemampuan membaca pada siswa kelas X SMA Negeri 6 Padang tanpa menggunakan media gambar ada kelas kontrol untuk indikator 1 sebesar 78,48 pada kualifikasi 'baik". Selanjutnya, perolehan rata-rata hitung kemampuan membaca pada siswa kelas X SMA Negeri 6 Padang dengan menggunakan media gambar pada kelas eksperimen sebesar 86,67 juga pada kualifikasi 'baik sekali'. Untuk indikator 2 diperoleh rata-rata hitung kemampuan membaca siswa kelas $\mathrm{X}$ SMA Negeri 6 Padang tanpa menggunakan media gambar pada kelas kontrol untuk indikator 2 sebesar 71,58 berada pada kualifikasi 'lebih dari cukup'. Perolehan rata-rata hitung kemampuan membaca siwa kelas X SMA Negeri 6 Padang dengan menggunakan media gambar kelas eksperimen sebesar 81,82 juga berada pada kualifikasi 'baik'. Untuk indikator \# diperoleh rata-rata hitung kemampuan membaca siswa kelas X SMA Negeri 6 Padang tanpa menggunakan media gambar pada kelas kontrol untuk indikator 3 sebesar 63,75 berada pada kualifikasi 'hampir cukup'. Perolehan rata-rata hitung kemampuan membaca siwa kelas X SMA Negeri 6 Padang dengan menggunakan media gambar kelas eksperimen sebesar 75,15 juga berada pada kualifikasi 'baik'.

Berdasarkan hasil uji-t, berarti kemampuan membaca siswa kelas X SMA Negeri 6 Padang dengan menggunakan media gambar lebih baik dari pada sebelum menggunakan media gambar. Jika dilihat dari $t_{\text {hitung }}$ dengan $t_{\text {tabel }}$ taraf signifikan $0,05 \%$ adalah 2,00 dengan derajat kebebasan $\mathrm{dk}=\mathrm{n} 1+\mathrm{n} 2-2$. Hal ini berarti thitung $>$ 
$\mathrm{t}_{\text {tabel }}(2,50>2,00)$. Jadi, dapat disimpulkan bahwa hipotesis diterima karena $t_{\text {hitung }}$ $>t_{\text {tabel }}$. Dengan kata lain, media gambar efektif terhadap kemampuan membaca oleh siswa kelas X SMA Negeri 6 Padang.

Berdasarkan hasil pengamatan saat proses pembelajaran, penggunaan media gambar fektif dalam pembelajaran dan membuat siswa dapat menguasai apa yang mereka pelajari, kondisi tersebut yang menyebabkan hasil belajar siswa kelas eksprimen lebih tinggi dari pada hasil belajar siswa kelas kontrol. Sehingga penggunaan media gambar pada pembelajaran membaca berpengaruh terhadap hasil belajar siswa kelas X SMA Negeri 6 Padang.

\section{KESIMPULAN}

Berdasarkan hasil penelitian, dapat disimpulkan tiga hal. Pertama, kemampuan membaca siswa kelas X SMA Negeri 6 Padang tanpa menggunakan media gambar berada pada kualifkasi cukup $(70,47)$. Kriteria Ketuntasan Minimal (KKM) kelas X SMA Negeri 6 Padang untuk mata pelajaran bahasa Jepang adalah 75. Jika KKM tersebut dibandingkan dengan rata-rata, maka kemampuan membaca siswa kelas X SMA Negeri 6 Padang tanpa menggunakan mediagambar belum memenuhi KKM.

Kedua, kemampuan membacasiswa kelas X SMA Negeri 6 Padang dengan menggunakan media gambar berada pada kualifkasi baik $(81,00)$. Kriteria Ketuntasan Minimal (KKM) kelas X SMA Negeri 6 Padang untuk mata pelajaran bahasa Jepang adalah 75. Jika KKM tersebut dibandingkan dengan rata-rata kemampuan membacasiswa kelas X SMA Negeri 6 Padang menggunakan media gambar sudah memenuhi KKM.

Berdasarkan hasil uji-t disimpukan bahwa terdapat pengaruh dari penggunaan media gambar terhadap kemampuan membacasiswa kelas X SMA Negeri 6 Padang karena $t_{\text {hitung }}$ besar dari $t_{\text {tabel }}(2,50>2,00)$. Jadi dapat disimpukan bahwa kemampuan membacasiswa kelas X SMA Negeri 6 Padang dengan diberi perlakuan menggunakan media gambar lebih baik dari pada tanpa menggunakan media gambar.

Selanjutnya, saran untuk peneliatn ini, bagi siswa diharapkan selalu aktif dalam mengikuti kegiatan pembelajaran sehingga dapat menghasilkan pengetahuan yang bersifat komprehensif baik afektif, psikomotor, dan kognitif serta mempersiapkan materi yang akan dipelajari terlebih dahulu. Bagi guru disarankan untuk menggunakan media gambar dalam pembelajaran dengan baik, khususnya untuk pembelajaran membaca. Hal tersebut bertujuan untuk menimbulkan motivasi dan memberi stimulasi kepada siswaagar mau membaca dan supaya siswa bisa paham apa yang mereka baca. Yang terakhir, untuk peneliti selanjutnya dapat menjadikan acuan bagi penelitian selanjutnya sebagai rujukan dan menghubungkan dengan manfaat yang akan diterima untuk menunjang 


\section{REFERENSI}

Arikunto,S.(2002). Metodologi Penelitian Suatu Pendekatan Proposal.Jakarta:PT. Bineka Cipta .(2006). Prosedur Penelitian Suatu Pendekatan Praktek. Jakarta: PT. Bineka Cipta .(2010). Prosedur Penelitian Suatu Pendekatan Praktek. Jakarta: PT. Bineka Cipta

Arsyad, Azhar. (2007). Media Pembelajaran. Jakarta: Raja Grafindo PersadaAR, Syamsudin.2006. Metode Penelitian Bahasa. Bandung: PT.Remaja Rosdakarya

Gerlach dan Ely. (1971). Teaching \& Media: A Systematic Approach Second Edition. By V.S Gerlach \& D.P. Ely, 1980, Boston, MA: Allyn andBacon. Copyright 1980 by Pearson Education

Maharsi, Indiria. (2002). Komik: Dunia Kreatif Tanpa Batas. Yogyakarta:Kata Buku Mc.Cloud, Scott. (2002). Understanding Comics. Memahami Komik.(Terjemah: S. Kinanti). Jakarta: KPG

Soenardi, M. (2011). Tes Bahasa: Pegangan Bagi Pengajar Bahasa. Jakarta:Indeks

Sudjianto. (2010). Metodelogi Pembelajaran Keterampilan Berbahasa Jepang. Bekasi: Kesaint Blank 